\title{
Perversion and Severe Personality Disorder: Perspective of Lacanian Psychoanalysis
}

\author{
Sang Bin Baek and You Jin Hong \\ Department of Psychiatry, College of Medicine, University of Ulsan, Seoul, Korea
}

\section{도착증과 중증 인격장애: 라깡 정신분석의 관점}

\author{
백 상 빈 · 홍 유 진 \\ 울산대학교 의과대학 정신건강의학교실
}

Today our age is moving from age of neurosis of hystery and obsession to age of perversion of narcissistic \& borderline syndrome. There is time background of this change, that is decline of patriarchy. Prolongation of infant-mother dyadic relationship in early developmental period and absence or weak father may break Oedipus complex and may result in pre-Oedipus complex pathology as borderline \& narcissistic personality disorder of modern psychiatric diagnosis and may result in perversion of Lacanian diagnosis. And generalization of narcissistic syndrome also shows decline of neurosis and prosperity of perversion. As a result of analysis of James Joyce, topological system of Lacan works to each subject relatively. Therefore goal of Lacanian psychoanalysis for jouissance need to be corrected to contain this relativism for subjects of different topological positions.

Psychoanalysis 2016;27(4):138-146

KEY WORDS: Topology $\cdot$ Perversion $\cdot$ Personality disorder $\cdot$ Sinthome $\cdot$ Jouissance.

Received: September 9, 2016 Revised: October 1, 2016 Accepted: October 3, 2016

Address for correspondence: Sang Bin Baek, MD, PhD

Department of Psychiatry, College of Medicine, University of Ulsan, 88 Olympic-ro 43-gil, Songpa-gu, Seoul 05505, Korea

Tel: +82-33-610-3187, Fax: +82-33-641-8070, E-mail: kohut1@naver.com

\section{서 론}

저자들은 자크 라깡 정신분석 이론의 임상진단범주와 현 대정신의학의 진단범주 중에서 특정한 진단의 연관가능성 을 살펴보고자 한다. 지그문트 프로이트와 자크 라깡의 정신 분석학은 그 동안 한국에서 각자의 독자적 학회를 구성하고 학술지를 발간하는 등 꾸준한 활동을 해왔으나 서로의 학문 적 교류는 부족하였다. 본 논문은 프로이트와 라깡 이론의 임상진단범주 중에서 서로 유사하게 연결되는 흥미로운 지 점이 있다는 것을 밝혀 보려고 한다.

재독 철학자 한병철은 그의 주저〈피로사회〉에서 시대마 다 그 시대에 고유한 주요 질병이 있다고 언급한 뒤 21세기 의 시작은 병리학적으로 볼 때 박테리아적이지도 바이러스 적이지도 않으며, 오히려 신경증적이라고 규정했다. 신경성

This is an Open Access article distributed under the terms of the Creative Commons Attribution Non-Commercial License (http://creativecommons.org/licenses/by-nc/3.0) which permits unrestricted non-commercial use, distribution, and reproduction in any medium, provided the original work is properly cited.
질환들, 이를테면 우울증, 주의력결핍과잉행동장애, 경계선 성격장애, 소진증후군 등이 21세기 초의 병리학적 상황을 지 배하고 있다고 하였다(Han 2010). 저자는 금세기의 주된 병 리학적 상황이 육체적 또는 물질적인 것보다는 심리적 혹은 정신적인 것에 연원한다는 그의 주장에 동의하며 더 나아가 한병철이 현시대의 대표 질환으로 꼽은 자발적 소진증후군 의 또 다른 이름으로, 라깡의 임상진단범주인 도착증(perversion)의 증후와 프로이트의 임상진단범주인 자기애성 인 격장애의 증후가 우리 시대에 점차 확산되어 이제는 만연한 상태임을 알아보려 한다. 그리고 라깡의 제임스 조이스 분석 에 대한 메타비평을 통하여 현재 라깡정신분석의 이론 및 임상이 지닐 수 있는 신경증적 편향을 지적하고 그와 더불 어 라깡 정신분석 이론의 위상학 체계가 지닌 상대성에 주 목하여, 이에 대한 응용을 통해 라깡 정신분석 임상의 목표 를 제시할 것이다. 


\section{본 론}

\section{현대 한국가정의 변화}

어느 평범한 대한민국 가정의 한 장면이다. 몸이 으슬 으슬한 게 몸살이라도 난듯하여 큰마음을 먹고 회사를 조퇴하고 집으로 돌아온 아버지. 아내는 친구 모임에라 도 나갔는지 집에는 아무도 없다. 그는 감기 몸살 약을 찾아 먹고는 거실 소파에 누웠다. 그러기를 한 시간여. 학교를 마친 중학생 아들이 열쇠로 문을 열고서는 집에 들어선다. '엄마! 엄마!' 하고 몇 번 불러 보더니 인기척 이 없자 소파에 누워 있는 아빠는 본체만체하고 집을 한 바퀴 둘러보고는 한마디한다. "어, 아무도 없네."

결코 웃을 수만은 없는, 이 서글픈 유머는 오늘날 가 정 내 '아버지의 부재'를 단면적으로 보여준다. '아버지 의 부재'는 말 그대로 물리적으로 '아버지가 집에 없거나 가족 행사에 함께 하지 않는다'라는 의미이고, 또 하나 는 아버지의 권위가 사라졌음을 의미한다(Ahn 2011).

이제는 한국사회에서 상식이 되어버린 아버지의 부재 혹 은 유령화라는 흐름은 이제 우리시대에 이르러 가부장제라 는 사회시스템이 쇠락하고 있음을 알려주고 있다. 현재 한국 의 가정은 그 시스템이 남성(아버지)이 아닌 여성(어머니)을 중심으로 재편되고 있다. 그 일례로 요즘 젊은 부부들은 육아 등 여러 가지 이유로 '시댁'보다는 '처가'가 생활반경의 중심 에 놓여 있는데, 이런 변화는 통계자료에서도 뚜렷하게 관찰 된다.

육아 등 경제적 이유로 처가살이를 하는 남성이 점점 늘어나고 있다. 24일 통계청의 '2010 인구주택 총조사' 결과에 따르면, 처가살이를 하는 남성은 20년 만에 3 배 (1990년 1만 8088명 $\rightarrow 2010$ 년 5만 3675명)로 늘어난 반면, 시집살이를 하는 여성은 절반 넘게(1990년 44만 4634명 $\rightarrow 2010$ 년 19만 8656명) 줄었다(Kim 2011a).

한국보건사회연구원이 21일 발간한 '부모 동거가 첫째 자 녀 출산에 미치는 영향' 논문에 따르면 친정어머니와 함께 사는 여성의 첫아이 출산 확률이 그렇지 않는 경우보다 2 배 이상 높았다. 20 39세 초혼 여성 579명의 출산아 수와 출산 시기를 담은 '한국노동패널' 10년 치(1998 2008년) 기록을 분석한 결과다. 반면 시부모나 친정아버지와의 동거 여부는 첫 출산과 별 상관이 없었다(Noh 2012).

우리사회의 가부장제가 쇠퇴하는 과정에서 가부장적 아버 지의 법은 새로운 내용을 지닌 법으로 전환될 가능성이 있다.
그리고 이러한 변화는 가정 내 자녀들의 심리발달 영역에서 예전에는 없었던 새로운 결과를 초래할 수 있다.

\section{오이디푸스 콤플렉스의 쇠퇴와 새로운 병리현상의 출현}

아버지가 사라져 가는 시대에서 프로이트와 라깡 정신분 석의 핵심개념인 오이디푸스 콤플렉스의 운명은 변화의 기 로에 놓이게 되었다. 라깡의 이론에서 오이디푸스 콤플렉스 란 아이와 일차양육자(어머니)의 2자 관계를 아이, 어머니, 아버지의 3자 관계로 변모시키는, 즉 주체를 상징계로 진입 시켜주는 필수적인 과정이다. 그런데 최근 들어 아버지의 존 재감과 영향력이 급격하게 쇠락함에 따라 오이디푸스 콤플 렉스의 과정이 충분히 이루어질 수 없는 상황에 처하게 되었 다. 즉 아이는 3 자 관계로 충분히 나아가지 못한 채 일차양 육자와의 2자 관계에 성장기의 오랜 기간 동안 계속 머물러 있게 된 것이다. 이러한 상황은 프로이트 정신분석의 관점에 서도 오이디푸스 콤플렉스 이전 시기(pre-oedipal period)의 발달문제에 기인하는 병리현상의 발생가능성을 높이게 되 는데, 그것은 자기애성 인격장애(narcissistic personality disorder)와 경계선 인격장애(borderline personality disorder)이다. 히스테리와 강박증으로 대표되던 프로이트의 고전 적 신경증 시대에서는 강조되지 않았던 이 인격장애들은 미 국의 정신분석가인 Kohut, Kernberg, Masterson, Gunderson 등이 본격적으로 연구하면서 널리 소개되었다. 이 두 성격장 애들은 강박증과 히스테리보다 더 심한 병리를 안고 있으며 치료 또한 매우 어렵다고 알려져 있다. Masterson(1988)은 이들에게서 더 심한 병리가 발생한 이유를 오이디푸스 콤플 렉스의 시기에 도달하기 이전인 pre-oedipal period에 이미 발달상의 심각한 문제가 발생하였기 때문이라고 설명하였 다. Klein은 생후 1 개월 정도의 발달 초기 단계에 본인 중심 의 편집-분열적 자리(paranoid-schizoid position)가 시작되 고 생후 6개월경부터 타인에 대한 고려를 할 수 있는 우울적 자리(depressed position)로 교체가 일어나는데, 인간이 우울 적 자리에 도달하는 것을 발달의 중요한 성취로 보았다 $(\mathrm{Li}$ 와 Yu 2016). Klein은 프로이트의 초자아가 시작되는 기원이 우 울적 자리와 관련되어 있으며 초자아가 이 발달단계를 공동 으로 결정하는 요소라고 보았는데(Kernberg 1980), 이는 오 이디푸스 시기를 거쳐야만 우울적 자리로 발달이 이루어질 수 있다는 것을 의미한다. 그러나 만약 오이디푸스 시기가 약 화되거나 결여될 경우, 아이는 편집-분열적 자리에 계속 머 무르게 되어 심각한 정신병리가 발생할 가능성이 높아지게 되는 것이다. 이렇듯 중증 인격장애 병리의 발생에서 전오이 디푸스기의 초기 발달과정은 가장 중요한 단서를 쥐고 있다. 임상치료에 있어서도 정신적 환경에 의한 상호작용 중 가장 
중요한 것은 초기 유아기의 모성과의 상호작용에 의한 모자 관계(child-mother relationship)이므로 실제 정신분석 임상 에서 신경증 환자들보다 좀 더 심한 정신병리를 가진 낮은 수준의 인격장애 환자들을 치료할 때, 환자와 치료자 사이에 이루어지는 상호작용의 발달이 정신분석의 치료요소로서 가장 중요한 것으로 강조되고 있다(Lis와 Yu 2016). 현대정신 의학 진단분류체계의 최신판인 Diagnostic and Statistical Manual of Mental Disorders, fifth edition(DSM-5) 인격장 애의 진단체계의 초기모델로 제시된 것은 정신분석적 모델 이 가장 중요한 뼈대로 작용하는데, 그중에서 초기발달의 병 리와 연관된 경계성 인격장애와 자기애성 인격장애는 정신 분석적 정신치료가 주요 치료방법으로 알려지면서 정신분석 의 영역에서 가장 많은 관심을 받고 있다(Choi와 Ha 2013).

저자는 본 논문에서 프로이트의 관점을 참고로 하여 라깡 정신분석의 관점에서 이 두 인격장애가 발생한 이유에 대한 가설을 세워 보겠다. 첫째, Masterson(1988)의 주장과도 같이, 오이디푸스 시기 이전 발달의 초기에 일차양육자(어머니)의 병리로 인해 아기와 어머니의 2자 관계 자체에 어떤 심각한 문제가 있었을 가능성을 먼저 생각해 볼 수 있다. 둘째, 초기 발달시기의 2자 관계에는 문제가 없었더라도 이후 제 3 자(아 버지)의 부재 혹은 무능에 기인하여 2자 관계가 과도한 상태 로 장기간 초과 유지됨으로 인해 오이디푸스 시기의 약화나 결여를 초래하여 결국 아이의 상징계 진입에 문제가 발생했 을 가능성을 생각해 볼 수 있다. 라깡의 관점에서 보았을 때, 주체가 발달의 과정에서 상징계에 정상적으로 진입하지 못 했다는 것은 곧 심각한 정신병리가 발생했다는 것을 의미하 는 것이다. 2016년 4월에 안산방조제 토막시신사건으로 구 속된 조씨에 대한 정신의학적 임상진단사례를 살펴보자. 2016년 5월 10일 방송된 YTN 뉴스에 출연한 정신건강의학 과전문의 Shin(2016)은 조 씨를 인격장애로 진단하였다.

저는 이 사건에 대해서 사이코패스다 아니다, 또는 소 시오패스이다, 이런 애기도 나오고 있는데요. 제가 보는 관점에서는 저는 성격장애의 측면에서 바라보고 있습니 다. 성격장애라 함은 일반적으로 보통사람하고 생각하 거나 행동하거나 감정의 반응이나 이런 부분이 달라서 그것으로 인해서 사회생활에 어려움이 있는 분들을 우 리가 성격장애라고 애기를 하는데요. 이 분 같은 경우에 는 자기애성 성격장애라고 하는 면에 매우 가깝다고 추 정이 됩니다. 자기애성 성격장애라고 할 때는 기본적으 로 자존감이 매우 낮은 사람이 과대한 자기 자신을 만들 려고 하고 타인에게 존경받으려고 한다든지 관심받으려 고 한다든지 이렇게 하는데 남들이 자기를 대단한 사람
으로 취급해 주지 않으면 굉장히 심하게 화를 내는데 특 히 무시당한다고 느끼는 상황에서 엄청나게 격분을 하 게 되는 특성이 있습니다(Shin 2016).

Shin(2016)은 조 씨의 임상진단에 대해 사이코패스 또는 소시오패스가 아니라 자기애성 인격장애라고 언급하였다. 이 진단들의 차이점에 대해 분석하기에 앞서, 이 뉴스방송에 서 특히 주목할 점은 조 씨가 죄송하다며 고개를 숙일 때의 표정이 사실은 웃는 것이라는 조 씨의 예전 회사동료의 인 터뷰 내용(Shin 2016)인데, 조 씨는 자신의 범행에 대해 전 혀 죄책감을 느끼지 않고 있으며 오히려 내심 비웃거나 즐거 워하고 있다는 것이다. 2016년 7월 일본에서 장애인 19명을 학살한 우에마쓰 사토시 역시 놀랍게도 취재진 앞에서 환하 게 웃는 모습을 보여주었다(Yoon 2016). 조 씨와 사토시가 자 신의 행동에 대해 윤리적 갈등이나 가책을 전혀 느끼지 않는 이유가 무엇인지 아는 것이 그들의 병리를 밝혀내는 데 있어 서 가장 중요한 사안일 것이다. 라깡 정신분석의 관점에서 저 자는 그 이유가 그들이 발달의 초기과정에서 정상적으로 상 징계에 진입하지 못했으며 그 결과(아버지의) 법이 내면화 되지 않았기 때문이라고 해석한다. 법의 내면화에 실패했기 때문에 그들은 현존 사회질서의 상징체계인 법, 도덕, 윤리 의 지배와 영향에서 벗어난 존재로 성장했던 것이다. 저자는 그들이 상식적 일반 상징계의 법 대신에 그와는 이질적인, 자 신만의 고유한 어떤 일탈적 법을 스스로 만들어 지니게 되 었다고 생각한다.

\section{도착증과 중증인격장애: 발생적 비교분석}

라깡의 이론에서 법은 주체가 오이디푸스 콤플렉스 시기 를 거쳐 상징계에 진입하는 과정에서 내면화된다. 이 과정에 는 초기양육자와의 2 자 관계를 떼어 놓는 제 3 자의 등장이 필 수적이다. 하지만 제 3 자의 부재 혹은 무능으로 인해 2자 관 계가 분리되지 않고 과잉 지속될 경우 주체는 도착증에 빠질 가능성이 높아진다. 라깡 정신분석 연구자 $\operatorname{Kim}(2011 \mathrm{~b})$ 은 도 착적 주체성의 문제를 다루며, 이러한 도착증 형성의 조건에 대해 "그것은 어머니와의 분리를 성사시켜야 하는 부성적 권 위의 개입기능이 부분적으로 실패했기 때문이다. 아이에 대한 ‘유혹'을 통해 전개되는 어머니의 리비도적 공모와 아버지의 존재에 대한 그녀의 애매한 침묵, 그리고 금지규범을 부과하 는 것에 대한 아버지의 의무태만과 어머니에 의해 상징적 특권을 박탈당한 것에 대한 그의 암묵적 방조는 결정적으로 아이를 도착적 동일시로 이끄는 요인들이다(Kim 2011b)"라 고 요약하였다. 그러므로 앞서 조 씨와 사토시의 행동이 도 착증의 범주에서 일어난 것이라면 $\operatorname{Shin}(2016)$ 이 지적했듯이 
그들의 정신의학적 진단을 자기애성 성격장애로 내리는 것 이 타당할 것이다. 왜냐하면 저자의 생각에 라깡의 세 가지 임상진단인 신경증, 도착증, 정신병 중 하나인 도착증은 현 대정신의학의 진단범주 중 자기애성 인격장애와 경계선 인 격장애에 대응될 수 있다. 그 이유는 정신병리 발생에 핵심 적인, 과거 발달과정에서의 공통점이 오이디푸스 콤플렉스 의 결여와 2자 관계의 초과 과잉이기 때문이다. 오이디푸스 이전의 발달과정에서 도착증의 범주인 자기애성 인격장애 와 경계선 인격장애를 발생시키는 초기양육자의 특성은 다 음과 같다.

아이를 도착증으로 유도했던 분리의 불안 못지않게 분리 불가능성의 불안도 아이에게는 위협적인 것이다. 어머니와의 직접적 관계 속에서 자신이 결국에는 결여 없이 전능한 어머니의 욕망에 삼켜지리라는 불안을 아 이는 견디기 어렵다. 뿐만 아니라 아이는 도착적 동일시 속에서 무제한적으로 주어지는 향유(jouissance)와 정비 례하여 증가하는, 무질서의 척도로서의 '심리적 엔트로 피' 또한 견디기 어렵다. 따라서 스스로 욕망의 주체로 서 존재하면서 무조건적 향유로부터 자기를 방어하기 위해 아이는 부권적 기능을 대체할만한 것을, 궁극적으 로는 '자기 자신의 욕망이라는 정언적 법'을 필요로 하 게 된다(Kim 2011b).

$\operatorname{Kim}(2011 b)$ 의 설명은 라깡적 범주에서 도착증의 발생을 정리한 것인데, 현대정신의학의 진단범주인 경계선 인격장 애와 자기애성 인격장애가 발달의 과정에서 어떻게 만들어 지는지 도착증 형성과정과의 유사점을 알려준다. 라깡의 관 점에서 $\operatorname{Kim}(2011 \mathrm{~b})$ 의 설명을 빌어 도착증의 발생에서 파생 된 경계선 인격장애의 핵심병리를 재해석하면 그것은 '분리 의 불안 못지않게 분리 불가능성의 불안도 아이에게는 위협 적인 것'이라는 것이다. 경계선 인격장애의 특징은 한마디로 대상과의 관계에서의 근원적 불안정성에 있다. 경계선 인격 장애자는 애착대상인 양육자와의 관계에서 매우 심각한 병 적 이중성에 놓이게 되는데, 하나는 대상에게서 버림받는 것 에 대한 공포이고 다른 하나는 대상에게 지배 흡수되어 소 멸되어버리는 것에 대한 공포이다. 이 때문에 경계선 인격장 애자는 한 대상에 대하여 끓임없이 이중적 태도를 왕복하게 된다. 대상에 근접하면 흡수될까 봐 도망가고 대상에게서 멀 어지면 버림받을까 봐 매달린다. 경계선 인격장애자들에게 는 대상과 적절한 거리를 유지하고 지내는 것이 불가능에 가 까울 정도로 어려운 것이다. 그러므로 경계선 인격장애가 발 생한 원인은 오이디푸스기 이전 초기발달의 시기에 분리의
불안과 분리불가능성의 불안이 동시에 공존하였기 때문이 며, 그 결과 경계선 인격장애자는 대상과 안정적 관계를 맺지 못하고 대상에 붙었다 떨어지는 계속적 진동(oscillation)만을 반복하게 되는 것이다. 다음으로 라깡의 관점에서 $\operatorname{Kim}(2011 \mathrm{~b})$ 의 설명으로 도착증의 발생에서 파생된 자기애성 인격장애 의 핵심병리를 재해석하면 그것은 '자기 자신의 욕망이라는 정언적 법(定言的 法)을 만드는 것'이다. 도착증의 발생에서 아이는 양육자와의 과도한 병적 2자 관계에서 양육자에게 동일시할 때 주어지는 향유(jouissance)를 감당하기 위해 아 버지의 법을 대체할 스스로의 법을 만들게 된다는 것인데, 상징계로부터 주어진 아버지의 법 대신에 자신의 단독적 법 을 만들어 집행한다는 것은 타인의 인정을 받지 못하는 초 라한 현실의 자기를 부인하고 그 대신 전지전능한 이상적 자 기(ideal self)를 만들어 스스로 그것을 자기 자신으로 인증하 는 자기애성 인격장애의 형성과정과 내용적으로 유사하다. 병적 2자 관계에서의 중압감을 이겨내고 1자로서 독립한 자 기애성 인격장애자는 모든 이의 상위에 군림하는 신과 같은 존재이다. 그는 최고로 훌륭하고 스마트하며 천재적이고 뛰 어나다. 그런 대단한 자기가 아직 현실에서 크게 성공하지 못하고 있는 단 하나의 이유는 단지 세상이 아직 그의 보석 과도 같은 진가를 모르고 있기 때문이다. 그의 법은 단연 최 상위에 있으므로 아버지의 법을 위시한 모든 상징계의 질서 를 초월하지만 아직 진정한 그의 시대가 오지 않았으므로 그 때까지는 세상의 법과 질서에 따르는 척을 해야 한다. 라깡의 진단범주로 볼 때 도착증자인 그는 아버지의 법이 내면화되 지 않았으며, 따라서 상징계의 질서에 포획되지 않은 완전한 자유인이다. 그러므로 그는 사법체제와 사람들의 감시에 걸 리지만 않는다면 언제든지 마음대로 어떠한 법이든 규칙이 든 도덕률이든 가차 없이 위반할 만반의 준비가 되어 있다. 그런 의미에서 그는 본질적으로 자기애성 인격장애자로 진 단되지만 추가적으로 반사회적 인격장애(antisocial personality disorder)의 진단 역시 충분히 가능한데, 이를 뒤집어 이야기하면 흔히 범죄자들을 분석할 때의 이런 저런 여러 정신의학적 진단들은 조현병 등 정신병의 경우를 제외하면 라깡적 의미에서는 사실상 도착증의 서로 다른 얼굴(이름) 들에 지나지 않다. 이에 대해 $\mathrm{Ha}$ 와 $\mathrm{Yu}(2011)$ 는 성인기의 사 이코패스를 이해하는 데 있어서 가장 근접한 진단적 개념은 자기애적 인격과 반사회적 인격이며 이 둘은 진단적으로도 많은 부분 중첩되므로 사이코패스는 두 인격장애의 연장선 을 아우르는 개념이라 이해하는 것이 유용하며, 발생학적으 로도 경계성 인격구조를 기반으로 하여 기질적 요인과 양육, 사회적 환경의 요인이 상호작용을 하면서 자기애적 경향과 반사회적 경향으로 각기 발달해 나가 하나의 스펙트럼을 형 
성하고 있는 정신구조로 이해된다고 정리하였다.

라깡은 도착증이 발생하는 데 있어 남녀의 경향성이 있는 지에 대해 언급한 바가 없다. 하지만 도착증과 유사하다고 생각되는 현대정신의학의 두 인격장애는 남녀경향성을 보 여주고 있다. 경계선 인격장애는 여성에게서 더 많이 나타나 고 자기애성 인격장애는 남성에게서 더 자주 보이는데, 그 이유는 무엇 때문인지 알아보자. 그것은 두 인격장애자가 성 장 시에 맺은 일차양육자와의 관계의 내용이 서로 다르기 때 문이다. 오이디푸스 콤플렉스 이전 시기의 일차양육자는 대 개 어머니이다. 최근 가정 내에서의 주도적 영향력은 부성에 서 모성으로 이동하고 있지만 아직은 과도기에 해당되며 여 전히 가부장제의 영향력과 흔적이 유효하게 작동하고 있다. 전형적인 가부장제에서 부모와 이성 자녀 사이의 친근감과 결합력은 아버지와 딸, 그리고 어머니와 아들 사이에서 더 강력하게 일어난다. 아버지는 이성 자녀인 딸에게 더 호감을 느끼며 허용적으로 되고 아들에게는 강압적이며 경쟁적으 로 대하기 쉽다. 과거 부성권력이 막강했던 가부장 시대의 절정기에는 가정 내 절대 권력자인 아버지의 비호와 유혹을 받으며 마치 연인처럼 과도하게 가깝게 지내던 딸들에게서 근친상간의 금기로 인한 무의식적 억압으로 인해 불감증적 히스테리아(hysteria) 환자들이 대거 양산되었을 것으로 추 정되며 이들 히스테리들에게 처음으로 진지하게 주목한 사 람이 바로 프로이트였던 것이다. 이때 아들들은 막강한 힘을 지닌 아버지의 억압으로 인해 자기조절에 대해 불안과 집착 을 지닌 강박증자로 성장하여 아버지의 권력 밑에서 숨죽이 며 자신이 나이를 먹어 동일한 권력을 지닐 시기만을 꿈꾸 며 기다렸는지도 모른다. 가부장 권력의 절정기에 어머니들 은 아무런 힘도 지니지 못한 채 남편에게 순종해야 했으며 자녀들에게도 별다른 영향을 미치지 못했다. 역사상 오랜 기 간 지속된 가부장제를 정신병리 역사의 관점으로 새롭게 정 의하자면 한마디로 '히스테리와 강박증의 신경증시대'라고 할 수 있겠다. 하지만 이제 가부장의 시대가 저물어가는 오 늘날 자녀들의 심리양태는 예전과는 다른 양상으로 변모하 고 있다. 그 대표적 특징이 바로 히스테리와 강박증이 점차 로 줄어들고 자기애인격과 경계선인격이 늘어나고 있는 현 상이다. 즉 정신병리 역사에서 이제 ‘히스테리와 강박증의 시 대'는 가고 '병적 자기애와 경계선 증후군의 시대' 또는 '도착 증의 시대(age of perversion)'가 오고 있는 것이다. 이렇게 정 신 병리의 양상이 바뀌게 된 이유는 두 가지다. 하나는 가정 내 아버지의 권력이 쇠락함에 따라 어머니의 자녀에 대한 영향력이 증대한 것이다. 다른 하나는 아버지의 쇠락과 연관 된 오이디푸스 콤플렉스의 결여로 인해 어머니와의 2자 관 계가 과도한 상태로 초과 장기화된 것이다. 어머니의 영향력
이 아버지보다 강력해진 상황에서 아들과 딸들은 과거 가부 장제와는 정반대의 처신을 요구받게 된다. 어머니는 이성 자 녀인 아들에게 더 호감을 느끼며 허용적이 되고 딸에게는 과도한 개입(over involvement)을 하기 쉽다. 아들들은 가정 내 새로운 권력자인 어머니의 전적인 비호와 유혹을 받으며 '도착적 동일시 속에서 스스로 욕망의 주체로서 존재하면서 무조건적 무제한적 향유로부터 자기를 방어하기 위해 아이 는 부권적 기능을 대체할만한 것을, 궁극적으로는 '자기 자 신의 욕망이라는 정언적 법'을 필요로 하게되는 것'이다. 이 러한 경로를 거쳐 아들은 일차양육자인 모친과의 병리적 2 자 관계 단계를 거친 뒤 진정한 1자인 자기애성 인격장애, 즉 도착증자로 성장하게 되는 것이다. 반면에 딸들은 새로운 실세인 어머니의 집요하고 과도한 개입으로 인해 '심각한 분 리의 불안과 분리 불가능성의 불안'을 동시에 느끼는 이중구 속의 상황에서 애착대상에게 매달리다 도망치는 진동의 단 계를 거쳐 자신의 내적 표상이 good과 bad로 분열되고 이를 끊임없이 타인에게 투사하는 경계선 인격장애, 즉 또 다른 종류의 도착증자로 성장할 수 있게 되었다. 가부장제하에서 모든 딸들이 병적 히스테리가 된 것은 아니었듯이, 저자 주 장의 요지는 가부장제의 쇠퇴에 따라 일반적인 가정에서 그 런 경향성의 변화가 생긴다는 것이다.

$\operatorname{Kim}(2011 \mathrm{~b})$ 은 〈김기덕 영화에서의 도착적 주체성의 문제〉 란 논문에서 김기덕 감독의 〈사마리아>에 등장하는 세 인물 들에 대하여 재영을 도착증으로, 여진은 도착증을 모방하는 신경증자로, 여진의 아버지인 영기를 강박증자로 진단한 바 있다. 그러한 진단의 근거에 대해서는 Kim(2011b)의 설명을 들어보면 충분하므로 생략하겠다. 다만 본 논문에서는 저자 의 논지에 근거해서 두 가지 추가하고 싶은 내용이 있다. 첫 째, 재영은 라깡의 진단범주에서 도착증이 분명하며, 더 나 아가 현대정신의학의 진단범주에서는 경계선 인격장애에 해당된다. 둘째, 여진의 아버지 영기에 대해 부권적 기능에 실패한 허약한 현대적 아버지로 묘사하며 "도착증자는 이런 아버지 밑에서 출현한다(Kim 2011b)"고 했는데, 이를 저자 의 주장대로 수정해서 표현하면 다음과 같다. "부권기능을 상실한 무능한 아버지와 강력한 모성권력을 지닌 지배적이고 과도 개입하는 어머니, 도착증자는 이런 어머니 밑에서 출현 한다.”

\section{조이스 분석과 라깡 정신분석의 목표}

후기의 라깡은 그의 위상학체계의 세 가지 위상(상상계, 상징계, 실재계)을 결합시켜 위상학적 안정성을 확보하는 중심점인 보로매우스 매듭을 유지시키는 제4의 존재로 생톰 (sinthome)이라는 개념을 도입한다. 주체의 증상(생톰)이 그 
의 위상학적 불균형을 바로잡아 주는 숨은 열쇠라는 것이다. Hong(2013)은 〈조이스의 증상(sinthome)〉에서 "조이스는 아 버지의 이름과 상징계가 작동하지 않았으므로 매듭이 완전 히 풀어질 수 있는 상황에서 자신의 증상, 즉 네 번째 고리를 발명함으로써 풀어질 수 있었던 보로매우스 매듭을 수선했 다.”며 소설가 제임스 조이스의 사례로 생톰을 설명하였다. $\operatorname{Kim}(2016)$ 역시 "생톰 개념을 통해 새로운 주체의 탄생을 소개함으로써 대중 일반이 실천적으로 활용할 수 있는 정신 분석적 주체론을 정립”하기 위해 조이스의 생톰 개념을 그 대표적 사례로 소개하였다.

상징계의 완고한 질서에 너무 질려 숨이 막혀서인지 주체 가 신경증적 오이디푸스 단계를 거치지 않고도, 또한 정신병 적 실재계에 잠식당하지 않고도 자기 안정화를 위해 스스로 의 노력만으로 새로운 상징계를 만들어 내는 것이 가능하다 는 주장은 상당히 매력적으로 들린다. 그래서 라깡이 어쩌다 가 이런 생톰이라는 신통한 개념을 발명하게 된 것인지 그 이유가 궁금해진다. 저자는 아마도 그것은 분석의 최종목표 를 제시하기 위해서였을 것이라고 생각한다. 이에 대해 라깡 정신분석가 부르스 핑크는 다음과 같이 정리하였다.

1960년대 초반에서 후반까지 이어지는 일련의 세미 나에서 라깡은 분석주체가 파기해야 할 것은 바로 (그의 욕망이 전개되는) 상징계 자체라는 논의를 전개한다. 이 후기의 관점에서 볼 때, 분석은 무의식적 욕망을 해체하 는 과정이 되는데, 왜냐하면 욕망은 분석주체가 대상 $\mathrm{A}$ 와 관계 맺는 것을 방해하고 주체의 만족을 가로막기 때 문이다. 욕망은 만족에 대한 방어이고, 욕망하는 주체는 충동하는 주체에 대한 방어이다. 욕망은 충동의 주이상 스를 간섭하고 방해한다. 욕망이라는 관점에서 분석을 바라보면, 분석과정은 곧 분석주체가 자신의 욕망을 완 성하기 위해 분석가의 욕망을 모방하는 과정으로 전락 할 위험이 있다. 이는 사실 환자의 허약한 자아를 분석 가의 건강한 자아와 동일시하는 것을 분석의 목적으로 하는 자아심리학과 매우 유사한 과정이다. 따라서 라깡 은 분석의 목표를, 타자의 욕망이라는 족쇄로부터 분석 주체를 분리하는 것으로 상정한다(Fink 1997).

Fink(1997)는 분석과정이 분석주체의 향유(jouissance)를 드러내는 방향이 되어야 한다고 주장했다. 분석주체가 충동 을 자신의 것으로 인정하는 과정이며, 그 결과 분석주체는 이드의 수준에서 자신의 만족을 추구할 수 있게 된다. 라깡 이 보기에 이러한 목표를 분석가와의 정신분석 과정 없이 스스로 달성한 사람이 바로 제임스 조이스였던 것이다. 이에
대해 Hong(2013)은 “라깡에 따르면 조이스는 기존의 억압 적인 상징계를 거부하고 새로운 상징계를 발명하고 그 창조 하는 행위에서 향유를 발견했다"고 언급했다. 이어서 “조이 스의 네 번째 고리의 역할이 타자, 그리고 의미의 차원이 전 혀 존재하지 않는 자폐적 상태, 혹은 자기만이 존재하는 상 태, 혹은 실재 속에서만 존재하는 상태라고 해석해서는 안 된다”고 설명했다. 저자 역시 조이스가 자폐증이었다고 생 각하지는 않는다. 하지만 아버지의 법에 연동되지 않고 생톰 이 만들어 낸 새로운 상징계(법)는 결국 도착의 범주를 벗어 날 수 없다. 그런 의미에서 저자는 조이스가 도착의 상태에 있었으며 그의 글쓰기는 도착의 승화라고 생각한다. 조이스 가 도착의 상태에 있었다고 해서 이를 무조건 병리적인 것 으로 해석해서는 곤란하다. 라깡에 따르면 인간은 '정신적 나약함'을 갖고 있으므로 증상 없는 순수한 정신의 상태를 유지하기가 불가능하며 따라서 네 번째 고리(증상)가 필요 하다(Hong 2013). 즉 인간이라면 누구나 라깡의 진단범주인 신경증, 도착증, 정신병 중 어느 하나에 반드시 속해 있게 마 련인 것이다. 단지 그것이 병리적 수준인지 아닌지가 임상적 으로 의미를 지닌다. 조이스는 스스로 자신의 법을 제정한 도착의 상태에 있었지만 병적 수준이 아니었으므로 도착의 경험을 통해 새로운 형태의 글쓰기를 창조해 낼 수 있었던 것이다. 사람들이 조이스에 열광하는 이유는 그가 상징계의 영역에 속해 있음에도 불구하고 그의 소설에는 결코 상징화 될 수 없는 실재의 영역이 함께 공존하고 있기 때문이다. 주 체가 신경증적 상징계의 영역에 주로 속해 있는 사람들은 이 불가지한 실재의 영역마저도 상징화해 내려는 욕망에 끊임 없이 유혹된다. 하지만 실재의 상징화는 상징계를 벗어날 수 없는 신경증자들에게는 근원적으로 불가능한 작업이다. 어 떤 해법, 구원, 탈출구를 찾아 상징화가 불가능한 영역인줄 알면서도 계속 시도하는 것, 이런 현상이 바로 신경증자들의 생톰이다. 앎이 우리를 구원할 것이라는 소망하에 신경증의 영역에서 끊임없이 이루어지는 라깡이론 해독에 대한 그노 시스적 접근 역시 라깡의 이론을 종교적 경전으로 성화시킬 위험이 있다. 스스로를 라깡주의자로 명명하고 자처하는 사 람들에게 라깡의 이론은 아버지의 이름으로 기능하며 “신경증 의 경우 아버지의 이름은 종교적 현실 그 자체(Hong 2013)” 인 것이다. 이때의 라깡은 바로 신경증자들의 라깡이다. 하 지만 라깡의 이론 자체는 그저 전체 상징계적 담론의 한 일 부분일 뿐이다. 이와 마찬가지로 조이스가 그토록 환멸을 느 끼며 적응하기를 부담스러워했던 더블린 사회도 그저 평범 한 일반 상징계적 질서의 하나였을 뿐이다. 바로 여기서 우 리는 라깡 위상학 체계의 상대성을 발견할 수 있다. 주체가 주로 신경증(상징계)의 영역에 속해 있는 사람들은 결코 도 
착증자(상상계)와 정신증자(실재계)를 온전히 이해할 수 없 다. 마찬가지로 주체가 주로 도착의 영역에 속해 있는 사람 들은 신경증자와 정신증자를 제대로 이해할 수 없는 것이다. 물론 한 주체는 상상계, 상징계, 실재계에 동시에 속해 있는 것이지, 어느 한 위상에만 속한 것은 아니다. 하지만 한 주체 에게는 자신의 생톰을 중심으로 특정한 위상이 지배적(dominant)으로 되며 이러한 이유로 각 주체들에게 위상의 상 대성이 발생하는 것이다. 도착의 범주에 머물렀던 조이스가 신경증 영역의 더블린 사람들을 도무지 이해할 수 없었던 이유도 이러한 위상의 상대성 때문이며 마찬가지로 신경증 자들은 조이스가 느꼈던 도착의 부조리를 공유할 수 없었기 때문에 조이스를 신경증의 세계로 끌어들여 설명(상징화)해 보려고 부단히 애를 써왔던 것이다. 조이스의 글을 읽은 사 람보다 조이스에 대한 논문을 쓴 사람이 더 많다는 농담이 나온 이유도 바로 이 때문이다. 만약 도착의 영역에 있는 사 람이 조이스의 소설을 읽는다면 아마도 그는 흥미를 느끼거 나 재미있게 즐기는 차원으로 끝나지, 연구를 하려고 들지는 않을 것이다. 그런 의미에서 프로이트의 슈레버 사례를 라깡 의 관점으로 해석했을 경우, 슈레버 판사의 망상적 상징계를 '거짓 상징계(Hong 2013)'라고 말할 수는 없다. 정신병자로 서, 주체가 주로 실재계의 영역에 머물고 있는 슈레버에게는 (신경증자들에게 병리증상으로만 파악되는) 망상적 상징계 가 상대적으로 진정한 '참 상징계'인 것이다. 조이스에게 실 제로 정신병의 조짐이 있었는지의 여부는 확실히 알려진 바 가 없다. 다만 그의 딸이 25세가 되던 해에 그녀에게 정신병 이 발병했던 사실로 볼 때 그에게 정신병과 연관된 유전적 취약성이 있었을 가능성은 생각해 볼 수 있다. 또한 조이스 는 '발병하지 않은 정신병자', 즉 ‘정신병적 구조를 갖고 있으 나 발병하지는 않았던 사람(Hong 2013)'일수도 있다. 그렇 기 때문에 아마도 그는 신경증과 정신병의 경계선 위에서 평생 동안 살았던 것인지도 모른다. 신경증도 정신병도 아닌 그 경계선은 다름아닌 바로 도착의 영역이다. 유추해 보건대 성장기의 조이스에게 아버지는 상징계 질서로의 편입을 강 제하는 대상이며 그런 한에서 두려움과 부담을 주는 대상이 었던 것으로 보인다. 이유나 경위가 어찌되었건 조이스는 '아버지의 이름을 거부(Hong 2013)'함으로써 오이디푸스 콤 플렉스의 과정을 통한 아버지와의 동일시에 이르지 못했으 며 그러한 도착의 상태에서 글쓰기를 통하여 자기만의 새로 운 상징계를 만들어야 했던 것으로 추정한다. 반면 조이스의 어머니는 그에게 매우 헌신적이었고 그를 끔찍하게 아껴주 었다고 한다. 이러한 상황은 아버지의 부재 및 그와 동시에 어머니와의 과도한 2자 관계가 지속되었을 가능성을 열어주 며 조이스에게 도착 혹은 자기애성 인격이 발생할 수 있는
배경이 된다. 그런 의미에서 조이스가 성인이 되어 평생을 함께했던 아내 노라는 상징계의 일반적 배우자의 자리가 아 니라 자신에게 헌신적이었던 어머니를 대체할 대상이며 도 착증자로서의 조이스에게 2자 관계를 지속시켜 줄, 죽은 어 머니의 연장선에 있는 또 다른 어머니였을 것이다. 그는 타 고난 재능을 통해 자신의 도착을 반 상징계적 행동화 대신 에 글쓰기로 승화시켰던 것이다. 여기서 주의해야 할 것은 조이스가 '발병하지 않은 정신병자(Hong 2013)'였기 때문에 그의 작품(실재계와의 연관성을 지닌 새로운 상징계 창조) 이 가능했던 것이지, 역으로 그의 글쓰기로 인해 정신병의 발병을 막은 것은 아니라는 점이다. "발병하지 않은 정신병 자'라는 말은 상징계의 시각에서는 유전적 생물학적 행운을 뜻하지만, 이러한 우연의 발생은 다분히 상징계로서는 가늠 하기 어려운 실재계의 영역에 속하는 것이다. 후기의 라깡에 게 조이스가 매우 중요한 인물이었던 이유는 라깡이 분석의 최종목표를 향유를 위해 상징계를 벗어나야 하는 것으로 설 정했기 때문이다. 신경증자로서의 라깡은 상징계를 벗어나 향유가 있는 실재계로 향하기 위하여 결국 자신에게는 미지 의 세계였던 도착의 영역을 필연적으로 답사해야만 했던 것 이며, 조이스는 그런 라깡에게 최고의 안내자가 되어주었던 것이다.

라깡이 생각한 분석의 최종 목표는 과연 현실의 임상에서 실제로 가능한 것인지 질문해 보자. 저자의 생각에 분석의 끝 은 '새로운 상징계를 창조하고 이를 통해 향유에 도달(Hong 2013)'하는 것이 아니다. 새로운 상징계 창조는 급진적 신흥 종교의 교주들에게서도 유사하게 찾아볼 수 있는데, 이들은 자신이 만든 새로운 세계관을 설파하여 신도들을 현실적 상 징계로부터 급격히 단절시키고 자신의 새로운 상징계(교리) 만을 추종하게 만든다. 하지만 자신만의 상징계를 창조한 교 주가 정말로 구원(향유)에 도달했는지는 결코 검증될 수 없 다. 라깡 정신분석 역시 어쩌면 신흥종교와 마찬가지의 입장 에 놓여 있다. 가끔 향유에 도달했다고 주장하는 사람의 간 증을 들을 수는 있겠지만 그가 정말로 향유에 도달했는지를 검증할 수 없기 때문에 옥석을 가릴 길이 없다. 또한 라깡 정 신분석의 목표인 분석의 과정을 통해서 상징계를 창조하려 는 작업은 그것을 감당할 피분석자의 상태를 염두에 두지 않거나 그러한 작업에 대한 피분석자의 명확한 동의여부에 대한 배려가 없다면 무책임하고 위험할 뿐만 아니라 또한 무의미한 행위일 수 있다. 정신분석가를 자처하는 사람들 사 이에서도 그들 중에 과연 누가 자신만의 상징계를 창조하여 향유에 도달했는지를 알아낼 방법이 없다.

저자가 직접적 - 개인적 임상경험을 통해 그동안 정립한 상담 및 분석의 목표는 고전적 라깡과는 다른 것이다. 저자 
의 분석목표는 개별적 피분석자 각각의 고유하고 특수한 위 상학적 심리체계를 안정화시키는 것이다. 피분석자는 어떤 증상(생톰)의 변화 혹은 악화로 인해 상담과 분석을 시작하 게 되는데, 이는 예전부터 유지해 온 자신만의 위상학적 균 형이 어떤 상황으로 인해 일시적으로 불안정하거나 위태롭 게 되었기 때문이다. 피분석자가 신경증자라면 분석가는 상 징계적 생톰(욕망과 불안)을 중심으로 한 그의 위상학 체계 가 현실적 자기균형을 되찾도록 도와주어야 한다. 피분석자 가 정신병자라면 분석가는 실재계적 생톰(이상체험과 혼란) 을 중심으로 구성된 그의 심리적 위상학 체계가 무너지지 않도록 지지해주어야 한다. 피분석자가 도착증자라면 분석 가는 상상계적 생톰(자아도취와 분노)을 중심으로 구성된 그의 위상학 체계를 안정시키면서 고유한 법을 병리적 행동 화로 표출하지 않고 예술 등의 자기만족적 작업으로 승화시 킬 수 있도록 격려해야 한다.

\section{결 론}

어떤 이론이나 학설이 그 시대의 주류를 형성하는 담론체 계를 구성하는 데 성공할 경우 그 이후에는 부작용이 뒤따 르게 되는데 그것은 이론으로 현실을 설명하려는 오류이다. 그 이론만 주로 습득하며 성장한 사람이거나 이론을 무비판 적 - 맹목적으로 수용한 사람일수록 오류의 가능성은 더욱 커진다. 나아가 이론을 신성시하고 종교적 수준에서 추종하 려는 사람들마저 생겨나는 경우가 있다. 하지만 이론으로 현 실을 재단하려는 시도는 결국 오류를 초래할 수밖에 없다. 그러므로 그와는 반대로 현실의 변화에 따라 이론은 이를 반영하고 설명하기 위해 수정 혹은 변경 등 스스로의 변화 를 모색하는 것이 타당한 것이다. 물론 그러한 노력에도 불 구하고 결국 현실을 반영하는 데 실패한 이론은 향후 폐기 될 운명에 처하게 될 것이다.

저자는 가부장제의 쇠퇴라는 시대적 전환기와 연관하여 라깡 임상진단의 도착증과 현대 정신의학진단(DSM-5)의 자기애성 인격장애, 경계선 인격장애가 유사한 병리적 소견 을 보일 수 있음을 소개하였다. 계통이 다른 두 임상진단체 계에서 이러한 정신병리상의 공통점이 발생한 이유는 가정 에서 제3자(아버지)의 약화에 따른 오이디푸스 콤플렉스 시 기의 쇠락과 그로 인해 결과된 아기-엄마 2자 관계의 초과 지속과 과잉으로 말미암아 전오이디푸스기 병리의 발생가 능성이 높아진 것에 기인한 것으로 생각되었다.

향후 정신분석 임상에서는 규율과 통제하에서의 억압에 발생적 기원을 둔 히스테리와 강박증 등 신경증 환자들만이 아니라 사회의 상징적 법의 내면화가 아닌 자신만의 개별적
법의 생성에 기원을 둔 도착증자들에게도 주의를 기울여야 할 필요가 있다고 생각한다. 도착증자의 정신분석을 위해 먼 저 라깡이 오이디푸스 콤플렉스 과정 없이도 자기치유에 성 공했다고 주장했던 제임스 조이스의 사례를 검토하였다. 이 과정을 통해 조이스의 도착증 가능성을 제기하고 그의 자기 치유방법에서 도착증의 정신분석에 대한 시사점을 얻을 수 있었다. 그리고 이를 통해 라깡 정신분석의 목표 또한 피분 석자의 향유(jouissance)추구보다는 좀 더 현실적인 수준으 로 수정되는 것이 필요하다는 결론을 내릴 수 있었다. 저자 에 의해 수정된 라깡 정신분석의 목표와 그에 따른 분석가 의 역할은 다음과 같다. 생톰을 중심으로 구성된 피분석자 각각의 개별적이고 고유한 상대적 위상체계 및 그것의 안정 성과 변동성 여부를 분석하고, 피분석자 자신만의 특별한 위 상체계가 무너지지 않도록 지지해주거나, 이미 불안정하고 위태롭게 변해버린 그의 위상체계가 다시 자기균형을 회복 하도록 도와주는 것이다.

앞으로 라깡의 정신분석 이론은 인간정신의 시대적 현실 적 변화를 보다 적절하게 설명하기 위해 프로이트 정신분석 이론, 분석심리학 이론, 자아심리학 이론, 대상관계 이론, 자 기심리학 이론, 현대정신의학 이론 등 우리시대의 주요한 심 리이론들과 교류하며 필요한 현실적 사안에서의 메타분석 과 그 결과에 따른 자기수정의 노력을 게을리하지 말아야 하 겠다.

\section{Conflicts of Interest}

The authors have no financial conflicts of interest.

\section{REFERENCES}

Ahn BM. Fathers are Disappearing. Ypsori. 2011 Oct 25.

Choi E, Ha JH. Challenge for the entry of psychoanalytic concepts in personality disorders in DSM-5. Psychoanalysis 2013;24:102-110.

Fink B. A clinical introduction to lacanian psychoanalysis: theory and technique. Cambridge, Mass: Harvard University Press;1997. p.364370.

Ha JH, Yu J. Various meanings of psychopathy. Psychoanalysis 2011;22: 27-33.

Han BC. Müdigkeitsgesellschaft. Berlin: Matthes \& Seitz Berlin Verlagsgesellschaft mbH;2010. p.11-12.

Hong JK. Joyce's sinthome: Lacan's clinic of the psychosis and the ethics of Joyce's symptoms. J Korean Soc Lacan Contemp Psychoanal 2013; 15:211-238.

Kernberg OF. Internal world and external reality: object relations theory applied. New York: Aronson;1980. p.55.

Kim JH. A Neo-matriarchal Society is coming. Chosun. 2011a Jul 25.

Kim SY. On the perverse subjectivity in Kim, Ki-Duk's films: focusing on Samaria. J Korean Soc Lacan Contemp Psychoanal 2011b;13:33-61.

Kim SY. Reading Žižek's The Ticklish Subject with Lacan's Seminar 23: exploring the concept of the subject beyond 'the Sinthome without Joyce' and 'the Dreadful Real'. J Korean Soc Lacan Contemp Psychoanal 2016;18:10-11.

Li EJ, Yu J. The importance of early attachment relationships in current psychoanalysis. Psychoanalysis 2016;27:54-61. 
Masterson JF. The search for the real self: unmasking the personality disorders of our age. New York: Free Press;1988. p.10-11.

Noh JH. Birthrate is determined by mother's mommy. DongA. 2012 Oct 23.
Shin DG. YTN news interview: Did Murderer Mr. Cho laugh? YTN. 2016 May 10.

Yoon H. A Japanese murderer who killed 19 disabled persons laughed delightfully. Ohmynews. 2016 Jul 28. 